American J. of Engineering and Applied Sciences 4 (1): 130-132, 2011

ISSN 1941-7020

C 2010 Science Publications

\title{
The Biodiesel Production from Roast Thai Sausage Oil by Transesterification Reaction
}

\author{
${ }^{1}$ Wasan Theansuwan and ${ }^{2}$ Kitrichai Triratanasirichai \\ ${ }^{1}$ Department of Mechanical Engineering, Mahasarakham University, \\ Kantharawichai District, Maha Sarakham 44150, Thailand \\ ${ }^{2}$ Department of Mechanical Engineering, Khon Kaen University, \\ Maung District, Khon Kaen 4002, Thailand
}

\begin{abstract}
Problem statement: This research is to study the feasibility of biodiesel production from roast Thai sausage oil by transesterification process. Approach: The objective of this study was to investigate the effects of potassium Hydroxide $\left(\mathrm{K}_{2} \mathrm{OH}_{3}\right)$ as heterogeneous catalyst (3-9\% (wt) of the feedstock) and methanol-oil molar ratio (3:1-12:1) on the yield and properties (flash point and fire point) of the biodiesel products at $60-{ }^{\circ} \mathrm{C}$ of reacting temperature. Results: The results showed that the suitable conditions for the production of biodiesel were at 3:1 of methanol-oil molar ratio and at $3 \%$ of $\mathrm{K}_{2} \mathrm{OH}_{3}$ (wt) of the feedstock. It was also found that the maximum biodiesel yields (86.40\%) on this condition. Conclusion: According to the physical characterisation of the products, it was found that the biodiesel produced in this study showed similar properties to the standard biodiesel (methyl ester).
\end{abstract}

Key words: Biodiesel production, transesterification reaction, roast Thai sausage, transesterification process, potassium Hydroxide, biodiesel yields

\section{INTRODUCTION}

Biodiesel, an alternative energy, is usually made from vegetable oils, animal fats or waste cooking oils mixed with alcohol. There are several techniques for biodiesel production oil such as transesterification, enzyme lipase, super critical fluid extraction, heterogeneous catalysts, pyrolysis. The transesterification reaction is a reaction of the oil with an alcohol to remove the glycerin, which is a by-product of biodiesel production (Hossain et al., 2008: Gerper, 2005; Marchetti et al., 2007).

In Thailand, the North-east people like to eat a roast food such as roast chicken, roast fish, roast pork and roast Thai sausage. The roast foods can get quite oil when on fire especially the roast Thai sausage.

The aim of this research is to study the feasibility of biodiesel production from roast Thai sausage oil by transesterification process.

\section{MATERIALS AND METHODS}

\section{Sample preparation:}

Roast Thai sausage oil: Roast Thai sausage oil (Fig. 1) obtained from the local areas of Maha Sarakham Province, Roast Thai sausage oil per a wheel shop is

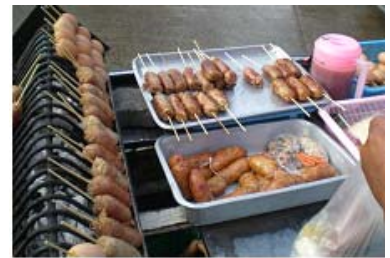

(a)

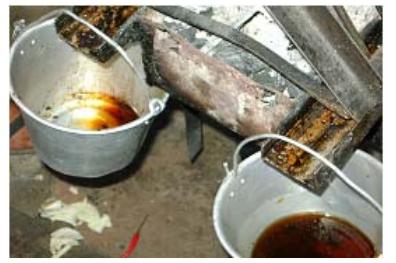

(b)
Fig. 1:The wheel shop of roast Thai sausage: (a) Thai sausage was roast over on the open fire (b) Roast Thai sausage oil

about $1.5 \mathrm{~L}^{\mathrm{day}^{-1}}$ (45 litres per month). Approximately, the wheel shops have 20-30 shop (9001350 litres per month) in Maha Sarakham Province.

Potassium hydroxide and methanol: Potassium hydroxide $\left(\mathrm{K}_{2} \mathrm{OH}_{3}\right)$ and methanol (98\% of purify) were purchased from Sahavithayasom Co., Ltd Khon Kaen, Thailand.

Experimental apparatus preparation: Figure 2 illustrates the schematic diagram of Biodiesel produce machine, which was designed by researcher. Briefly, it consists of heating system, air compressor, reaction chamber and measurement instruments. The reaction tanks were made from $0.8 \mathrm{~mm}$-stainless steel thick. The

Corresponding Author: Wasan Theansuwan, Department of Mechanical Engineering, Mahasarakham University, Kantharawichai District, Maha Sarakham 44150, Thailand 


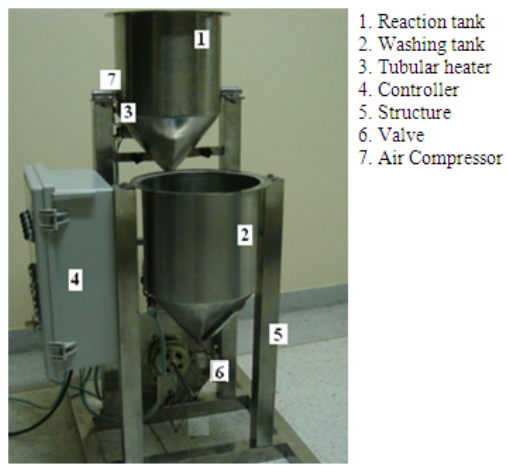

Fig. 2: Biodiesel produce machine

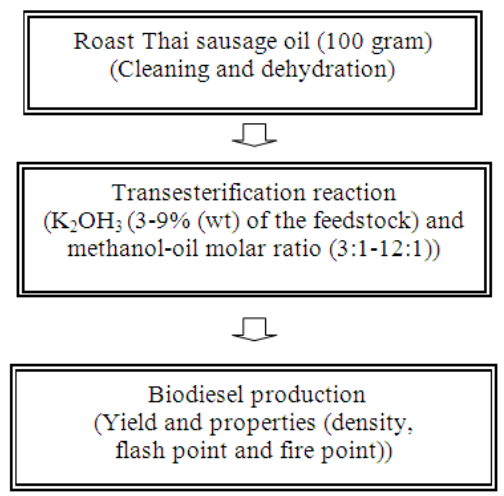

Fig. 3: The biodiesel production from roast Thai sausage oil by Transesterification reaction

tubular heater was made from stainless steel $2 \mathrm{~kW}-220$ $\mathrm{V}$ of $\varnothing 8.5 \mathrm{~mm}$. The compressor air (MY and CARR) was $12 \mathrm{~V}-10 \mathrm{~A}$ (DC) with adapter.
Experimental method: The production of biodiesel from Roast Thai sausage oil by biodiesel produce machine 10 liter, were applied as raw material for biodiesel production via transesterification employing potassium hydroxide $\left(\mathrm{K}_{2} \mathrm{OH}_{3}\right)$ as catalyst. The reaction used potassium hydroxide $\left(\mathrm{K}_{2} \mathrm{OH}_{3}\right)$ as heterogeneous catalyst (3- 9\% (wt) of the feedstock) and methanol-oil molar ratio (3:1-12:1) on the yield and properties (flash point and fire point) of the biodiesel products at $60^{\circ} \mathrm{C}$ of reacting temperature (Fig. 3).

\section{RESULTS AND DISCUSSION}

The highest Yield (86.40\%) of biodiesel production from roast Thai sausage oil was obtained at 3:1 of methanol-oil and $3 \%$ of $\mathrm{K}_{2} \mathrm{OH}_{3}$ ((wt) of the feedstock) and the lowest yield was 60.75 at 12:1 of methanol-oil and $9 \%$ of $\mathrm{K}_{2} \mathrm{OH}_{3}$ ((wt) of the feedstock) as showed in Table 1.

Flash point (Fig. 4) and fire point (Fig. 5) of biodiesel production from roast Thai sausage oil was obtained the range of 125.5-177.5 and 129.1-179.2 at 3:1-12:1 of methanol-oil and 3-9 \% of $\mathrm{K}_{2} \mathrm{OH}_{3}((\mathrm{wt})$ of the feedstock), respectively.

\section{CONCLUSION}

Biodiesel production from roast Thai sausage oil can be produced successfully using the Transesterification reaction with methanol (98\% of purity) employing $\mathrm{K}_{2} \mathrm{OH}_{3}$ as a catalyst. The suitable conditions for the production of biodiesel were at 3:1 of methanol-oil molar ratio and at $3 \%$ of $\mathrm{K}_{2} \mathrm{OH}_{3}$ (wt) of the feedstock. It was also found that the

Table 1: Yield of biodiesel production from roast Thai sausage oil

\begin{tabular}{|c|c|c|c|c|}
\hline \multirow{3}{*}{$\begin{array}{l}\text { Methanol-oil } \\
\text { molar ratio }\end{array}$} & \multicolumn{4}{|c|}{$\mathrm{K}_{2} \mathrm{OH}_{3}((\mathrm{wt})$ of the feedstock) (\%) } \\
\hline & 3 & & & \\
\hline & Biodiesel (g)/Yield (\%) & 5 & 7 & 9 \\
\hline $3: 1$ & $91.50 / 86.40$ & $92.03 / 84.88$ & $90.15 / 83.05$ & $89.30 / 81.40$ \\
\hline $6: 1$ & $90.36 / 77.79$ & $80.49 / 74.33$ & $80.22 / 72.91$ & $88.33 / 73.53$ \\
\hline 9:1 & $89.20 / 70.57$ & $80.07 / 67.13$ & $89.99 / 68.60$ & $89.71 / 67.50$ \\
\hline $12: 1$ & $92.81 / 65.63$ & $83.21 / 62.19$ & 83.91/61.47 & $84.51 / 60.75$ \\
\hline
\end{tabular}

Yield $(\%)=($ biodiesel product $/$ the whole of raw product $) \times 100$

Table 2: Comparison of physical property between Methyl Ester (100 and 10\%), Business Energy Department and biodiesel products from the experiments at $3 \%$ of $\mathrm{K}_{2} \mathrm{OH}_{3}$ and 3:1 of methanol-oil ratio

\begin{tabular}{|c|c|c|c|c|}
\hline \multirow[b]{2}{*}{ Description } & \multirow[b]{2}{*}{ Business Energy Department } & \multicolumn{2}{|c|}{$\begin{array}{l}\text { Methyl Ester } \\
\text { (Ma and Hanna, 1999) }\end{array}$} & \multirow{2}{*}{$\begin{array}{l}\text { Biodiesel products from the } \\
\text { experiments at } 3 \% \text { of } \mathrm{K}_{2} \mathrm{OH}_{3} \text { and } \\
\text { 3:1 of methanol-oil molar ratio } \\
\text { Roast Thai sausage oil }\end{array}$} \\
\hline & & $100 \%$ & $10 \%$ & \\
\hline Flash point, ${ }^{\circ} \mathrm{C}$ (ASTM 93) & $>120$ & 152 & 69.2 & 161.4 \\
\hline Fire point, ${ }^{\circ} \mathrm{C}$ (ASTM 93) & - & 188 & 84 & 179.8 \\
\hline
\end{tabular}




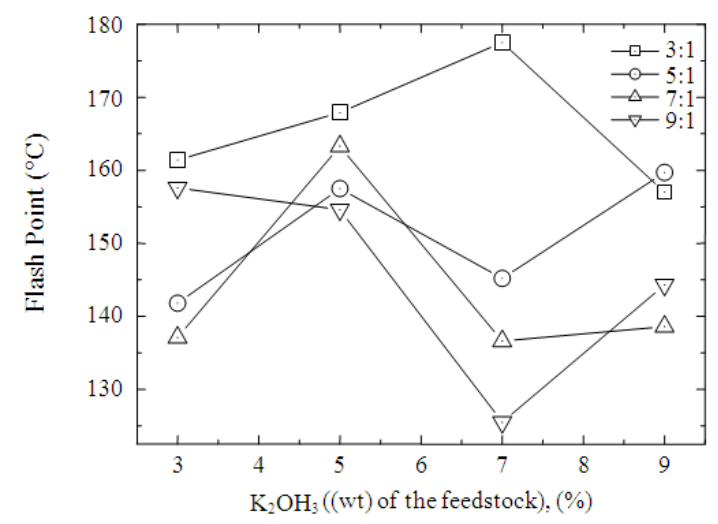

Fig. 4: The relationship between flash point of biodiesel at different methanol-oil molar ratio and $\mathrm{K}_{2} \mathrm{OH}_{3}((\mathrm{wt})$ of the feedstock) (\%)

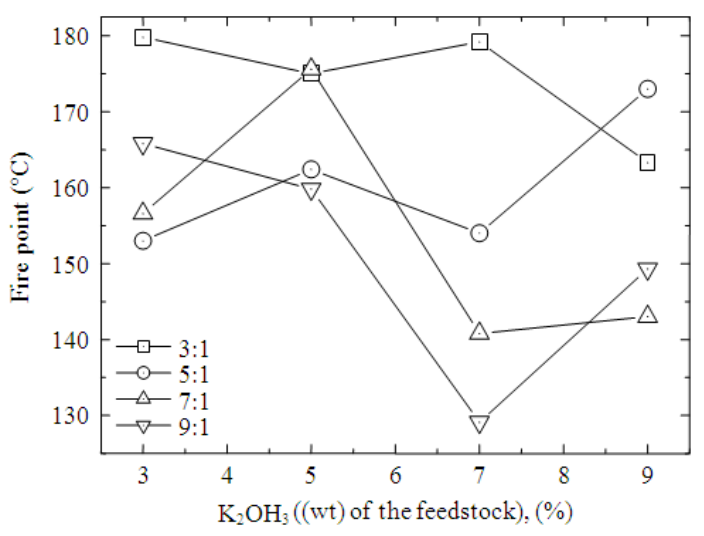

Fig. 5: The relationship between fire point of biodiesel at different methanol-oil molar ratio and $\mathrm{K}_{2} \mathrm{OH}_{3}$ ((wt) of the feedstock) (\%) maximum biodiesel yields (86.40\%) on this condition. According to the physical characterisation of the products, it was found that the biodiesel produced in this study showed similar properties to the standard biodiesel (methyl ester) (Table 2).

\section{ACKNOWLEDGMENT}

This research is financially supported by Mahasarakham University and National Research of Thailand, Thailand.

\section{REFERENCES}

Gerper, J.V., 2005. Biodiesel processing and production. Fuel Proc. Technol. 86: 1097-1107. DOI: 10.1016/j.fuproc.2004.11.005

Hossain, A.B.M.S., A. Salleh, A.N. Boyce, P. chowdhury and M. Naqiuddin, 2008. Biodiesel fuel production from algae as renewable energy. Am. J. Biochem. Biotechnol., 4: 250-254. DOI: 10.3844/ajbbsp.2008.250.254

Ma, F. and M.A. Hanna, 1999. Biodiesel production: A review. Biores. Technol., 70: 1-15. DOI: 10.1016/S0960-8524(99)00025-5

Marchetti, J.M., V.U. Miguel and A.F. Errazu, 2007. Possible methods for biodiesel production. Renewable Sustainable Energy Rev., 11: 1300-1311. DOI: 10.1016/j.rser.2005.08.006 